\title{
REVIEW
}

Intisari Sains Medis 2020, Volume 11, Number 1: 60-65

P-ISSN: 2503-3638, E-ISSN: 2089-9084

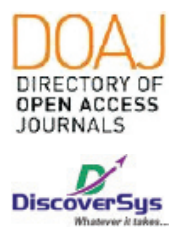

Published by DiscoverSys

\section{Central Retinal Vein Occlusion: A Literature Review}

\author{
Ni Putu Ayu Reza Dhiyantari, Listya Dyah Rihardini
}

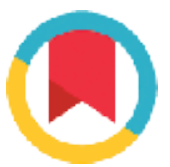

CrossMark

\section{ABSTRACT}

Introduction: Central retinal vein occlusion is vascular eye disease commonly found at ophthalmologist daily practice and also responsible for a large percentage of blindness and eye morbidity. Early diagnosis and prompt treatment may elaborate the disease and slow down disease progression.

Methods: Literature review was carried out, where studies were identified through searching the PubMed, Google Scholar and Proquest database using the keywords: "central retinal vein occlusion", "anti-VEGF", "intraocular corticosteroid", "retinal imaging", "macular oedema". Inclusion criteria include any reviews on CRVO. Exclusion criteria was reviews which were published more than 10 years ago. From 75 reviewed journals, 55 journals were included. The literatures were then analysed systematically based on the results of previous studies.
Results: CRV0 can be diagnosed clinically based on anamnesis, general physical examination to evaluate risk factors related to the disease and also based on routine ophthalmologic examination. Advanced imaging modalities are useful mainly to evaluate severity of the disease, to choose treatment modalities and also to evaluate disease response to therapy. CRV0 management has two main goals, namely (1) to identify major risk factor underlying the disease and control it, (2) to diagnose sight threatening complications of CRV0, such as macular oedema and neovascularisation and to manage them.

Conclusion: Current CRVO treatment modalities includes antiVEGF and corticosteroid implants have been extensively studied in big clinical trials and already proven clinically to treat CRVO related macular oedema.
${ }^{1}$ Klinik Mata Ayu Siwi, Nganjuk, Jawa Timur

${ }^{*}$ Correspondece to: Ni Putu Ayu Reza Dhiyantari; Klinik Mata Ayu Siwi, Nganjuk, Jawa Timur;

ayurezareza@gmail.com
Keywords: central retinal vein occlusion, anti-VEGF, intraocular corticosteroid, retinal imaging, macular oedema

Cite this Article: Dhiyantari, N.P.A.R., Rihardini, L.D. 2020. Central Retinal Vein Occlusion: A Literature Review. Intisari Sains Medis 11(1): 61-65. DOl: 10.15562/ism.v11i1.562

\section{ABSTRAK}

Pendahuluan: Oklusi vena sentral mata (central retinal vein occlusion/ (RV0) merupakan penyakit vaskular mata yang sering dijumpai pada praktek sehari-hari dan bertanggung jawab atas sejumlah kebutaan dan morbiditas pada mata sehingga diagnosis dini dan penatalaksanaan yang tepat dapat meningkatkan keberhasilan terapi dan mencegah komplikasi lebih lanjut

Metode: Metodologi penulisan yang digunakan adalah tinjauan pustaka. Sumber literatur terdiri dari jurnal-jurnal yang relevan dari search engine PubMed, Google Scholar dan Proquest. Kata kunci yang digunakan adalah "central retinal vein occlusion", "anti-VEGF", "kortikosteroid intraocular", "pencitraan retina", "edema makula". Kriteria inklusi adalah semua tinjauan mengenai CRVO. Kriteria eksklusi adalah literatur yang diterbitkan lebih dari 10 tahun terakhir. Dari 75 jurnal yang ditinjau, 55 ditemukan cocok sebagai referensi untuk makalah ini. Informasi yang dikumpulkan dicatat dan dianalisis untuk validitas dan reliabilitas, ditafsirkan dan disusun menjadi satu kajian literatur ilmiah.

Hasil: Diagnosis CRVO dapat ditegakkan secara klinis berdasarkan anamnesis, pemeriksaanfisikumum, serta pemeriksaan ophthalmologis rutin. Pemeriksaan pencitraan penunjang dibutuhkan terutama untuk menilai derajat keparahan penyakit, mempertimbangkan tindakan atau pengobatan, serta berguna dalam menilai respon terapi. Penatalaksanaan CRVO memiliki dua tujuan utama yaitu mengidentifikasi dan mengontrol faktor risiko mayor yang mencetuskan CRV0 serta mendiagnosis dan menangani komplikasi yang mengancam penglihatan, terutama edema makula dan neovaskularisasi.

Kesimpulan: Penatalaksanaan CRVO saat ini sudah mengalami perkembangan yang pesat dengan banyaknya modalitas baru termasuk anti-VEGF dan implant kortikosteroid yang telah terbukti secara klinis mampu mengobati edema makula terkait CRV0
Diterima: 09-04-2019

Disetujui: 21-09-2019

Diterbitkan: 03-03-2020
Kata kunci: central retinal vein occlusion, anti-VEGF, kortikosteroid intraokular, pencitraan retina, edema makula

Cite Pasal Ini: Dhiyantari, N.P.A.R., Rihardini, L.D. 2020. Oklusi Vena Sentral Retina: Tinjauan Pustaka. Intisari Sains Medis 11(1): 61-65. D0I: 10.15562/ism.v11i1.562 


\section{PENDAHULUAN}

Retinal vein occlusion (RVO) adalah penyakit pembuluh darah retina nomer dua terbanyak setelah retinopati diabetic. ${ }^{1}$ Sebuah analisa dari beberapa penelitian berbasis populasi di Amerika Serikat, Australia, Eropa dan Asia memperkirakan prevalensi total RVO sebesar 16,4 juta jiwa, dengan 2,5 juta jiwa menderita CRVO dan 13,9 juta jiwa menderita Branch RVO (BRVO). ${ }^{2}$ Insiden CRVO akan meningkat sesuai bertambahnya usia dimana lebih dari separuh kasus terjadi pada usia 65 tahun ke atas. Beberapa penelitian menunjukkan bahwa laki-laki memiliki risiko lebih tinggi menderita CRVO dibandingkan dengan perempuan, namun penelitian lain menunjukkan hasil yang tidak konsisten. ${ }^{1,2}$

RVO terjadi akibat adanya obstruksi parsial atau komplit pada vena retina. RVO diklasifikasikan berdasarkan lokasi obstruksi, yaitu pada pembuluh darah vena retina sentralis atau di cabang-cabang vena retina. Oklusi vena retinal sentral atau Central retinal vein occlusion (CRVO) dapat mengakibatkan kebutaan permanen apabila tidak ditangani dengan baik sehingga diagnosis dini dan penatalaksanaan yang tepat merupakan kunci keberhasilan terapi CRVO. ${ }^{1,2}$

Secara klinis CRVO digambarkan dengan berkurangnya penglihatan atau kebutaan yang bersifat tiba-tiba dimana pada pemeriksaan fundus dapat ditemukan adanya pendarahan retina, vena retina yang melebar dan berkelok-kelok, cotton-wool spot, edema macula dan edema diskus optikus. ${ }^{3}$ CRVO dapat diklasifikasikan berdasarkan area kapiler retina yang teroklusi dan derajat perkembangan neovaskularisasi.

CRVO secara umum dapat dibagi menjadi dua tipe klinis yaitu iskemik dan non-iskemik. Namun dalam prakteknya dapat ditemukan kasus-kasus yang intermediet yaitu berada ditengah-tengah antara kedua tipe tersebut dengan perjalanan klinis yang bervariasi. ${ }^{3}$ Lebih dari $80 \%$ kasus intermediet pada akhirnya akan mengalami progresi kearah iskemik. ${ }^{4}$ Pada awal presentasi kasus dapat pula terjadi kesulitan dalam mengklasifikasikan kasus tersebut ke dalam salah satu kategori karena CRVO dapat berubah-ubah dari non-iskemik menjadi iskemik seiring berjalannya waktu.

Non-ischemic CRVO adalah bentuk yang lebih ringan dimana penglihatan mungkin masih baik, tidak ada relative afferent pupillary defect (RAPD), serta perfusi ke retina masih baik. Pada pemeriksaan funduskopi dapat ditemukan cabang-cabang pembuluh darah retina sentralis yang dilatasi dan berkelok ringan, dapat pula ditemukan sedikit perdarahan retina (dot maupun flame-shaped) dan cotton-wool spot di semua kuadran retina. ${ }^{3}$ Dapat terjadi resolusi total pada non-ischemic CRVO dengan hasil penglihatan yang baik, namun apabila tidak terdeteksi di awal dan tidak ditangani dengan baik maka dapat pula berkembang menjadi ischemic CRVO. ${ }^{1}$

Ischemic CRVO adalah bentuk yang lebih berat. Pasien mungkin datang pertama kali dengan gambaran klinis awal sebagai ischemic CRVO atau dapat juga sebagai perkembangan dari non-ischemic CRVO. Ischemic CRVO biasanya memiliki klinis gangguan penglihatan yang berat, perdarahan retina dan cotton wool spot yang luas, terdapat RAPD, perfusi ke retina yang buruk, dan adanya temuan yang mengindikasikan suatu oklusi berat pada pemeriksaan fundus fluorescein angiography. ${ }^{4}$ Komplikasi lanjut dari suatu CRVO yang berat yaitu kebutaan permanen dan glaukoma sekunder akibat proses neovaskularisasi. ${ }^{3}$

\section{METODE}

Metodologi penulisan yang digunakan adalah tinjauan pustaka. Sumber literatur terdiri dari jurnal-jurnal yang relevan dari search engine PubMed, Google Scholar dan Proquest. Kata kunci yang digunakan adalah "central retinal vein occlusion", "anti-VEGF", "kortikosteroid intraocular", "pencitraan retina", "edema makula". Kriteria inklusi adalah semua tinjauan mengenai CRVO. Kriteria eksklusi adalah literatur yang diterbitkan lebih dari 10 tahun terakhir. Dari 75 jurnal yang ditinjau, 55 ditemukan cocok sebagai referensi untuk makalah ini. Informasi yang dikumpulkan dicatat, dan dianalisis untuk validitas dan reliabilitas, ditafsirkan dan disusun menjadi satu kajian literatur ilmiah.

\section{HASIL DAN PEMBAHASAN}

\section{Patofisiologi}

Patofisiologi oklusi trombotik pada vena retina sentralis tidak diketahui secara pasti. Berbagai faktor lokal dan sistemik berperan dalam oklusi patologis vena retina sentralis. Arteri dan vena retina sentralis berbagi selubung adventisial yang sama di ujung keluarnya pembuluh darah pada nervus optikus dan lamina kribrosa. Jalur pembuluh darah pada lamina kribrosa begitu sempit sehingga pembuluh darah berada dalam kompartemen yang tidak memungkinkan terjadinya pergeseran maupun dilatasi. ${ }^{5}$

Terbentuknya arteriosklerosis pada arteri retina sentralis mengubah struktur dinding arteri menjadi kaku dan akhirnya mempengaruhi vena retina sentralis yang memiliki struktur lebih lentur. Kejadian tersebut menyebabkan gangguan hemodinamik, kerusakan endotel dan pembentukan 
trombus. Mekanisme ini menjelaskan fakta bahwa dengan ditemukannya suatu CRVO maka sangat mungkin ada penyakit arteri yang berhubungan dengan kondisi tersebut. Asosiasi antara penyakit arteri dengan CRVO masih belum dapat dibuktikan secara konsisten. ${ }^{5}$

Oklusi trombotik pada vena retina sentralis dapat terjadi sebagai hasil dari beragam gangguan patologis, termasuk tekanan mekanis pada vena (misalnya akibat perubahan struktural lamina kribrosa yang terjadi pada glaucomatous cupping, pembengkakan nervus optikus akibat inflamasi, dan penyakit orbita), gangguan hemodinamik, perubahan pada dinding pembuluh darah (misalnya vaskulitis) dan perubahan pada darah (misalnya defisiensi faktor trombolitik darah atau meningkatnya faktor pembekuan darah). ${ }^{6}$

Terjadinya oklusi pada vena retina sentralis mengakibatkan terjadinya peningkatan volume darah pada sistem vena retina dan meningkatnya resistensi aliran darah vena. Peningkatan resistensi ini menyebabkan stagnasi dan kerusakan iskemik pada retina. Kerusakan iskemik pada retina kemudian menstimulasi peningkatan produksi vascular endothelial growth factor (VEGF) didalam kavitas vitreous. ${ }^{6}$ Peningkatan level VEGF menstimulasi pembentukan neovaskular di segmen posterior dan anterior. Proses neovaskularisasi di segmen anterior inilah yang bertanggung jawab terhadap komplikasi sekunder CRVO terhadap segmen anterior mata. VEGF juga memicu kebocoran pada dinding kapiler, yang kemudian mengakibatkan edema pada makula. Edema makula dapat terjadi baik pada ischemic CRVO maupun non-ischemic CRVO dan merupakan penyebab utama terjadinya kebutaan. ${ }^{7}$ Prognosis CRVO tergantung pada kemampuan mata untuk melakukan rekanalisasi yaitu pembentukan kembali patensi sistem vena, seberapa banyak gumpalan darah yang dapat diserap serta pembentukan optocilliary shunt vessels. ${ }^{8}$

\section{Gambaran Klinis}

Anamnesis lengkap terutama berkaitan dengan penyakit sistemik yang diderita maupun faktor lokal lain yang merupakan predisposisi terhadap CRVO harus selalu digali. Riwayat penyakit yang signifikan berhubungan dengan CRVO antara lain: ${ }^{6}$

- Hipertensi

- Diabetes mellitus

- Penyakit kardiovaskular

- Penyakit gangguan pembekuan darah

- Vaskulitis

- Penyakit autoimun

- Penggunaan kontrasepsi oral

- Trauma kepala
- Konsumsi alkohol

- Aktivitas fisik yang berat

- Glaukoma primer sudut terbuka atau tertutup

Pasien dapat datang dengan atau tanpa keluhan pada penglihatan. Gejala yang sering didapatkan pada pasien dengan indikasi CRVO yaitu: ${ }^{3}$

- Penglihatan kabur

- Gangguan penglihatan/ kabur dapat dikeluhkan terjadi secara tiba-tiba atau perlahan selama beberapa hari atau beberapa minggu. Gangguan penglihatan dapat bervariasi dari gangguan sementara yang membaik dengan sendirinya (biasanya pada awalan perjalanan penyakit) kemudian lama-kelamaan menjadi konstan.

- Fotofobia/silau

- Kebutaan yang disertai nyeri pada mata yang bersangkutan

- Mata merah

Gejala-gejala lain seperti penglihatan buram, nyeri pada mata, rasa tidak nyaman, mata berair maupun mata merah dapat dikeluhkan pada mata dengan CRVO yang sudah lama.

\section{Pemeriksaan Fisik}

Pasien dengan CRVO harus menjalani pemeriksaan mata lengkap termasuk pemeriksaan visus, refleks pupil, pemeriksaan lampu celah untuk mengevaluasi segmen anterior dan posterior mata, gonioskopi, pemeriksaan fundus. ${ }^{9}$

Pemeriksaan visus untuk menilai penglihatan terkoreksi terbaik harus selalu dilakukan karena dapat memprediksi prognosis. Refleks pupil dievaluasi untuk mengetahui ada atau tidaknya RAPD. Apabila terdapat pembuluh darah abnormal pada iris maka kemungkinan reflek pupil negatif. ${ }^{3}$ Kongesti konjungtiva dan pembuluh darah silier dapat ditemukan pada kasus yang berat. Pada iskemik CRVO yang berat dan sudah lama mungkin didapatkan pembuluh darah abnormal akibat neovaskularisasi pada iris. Pembuluh darah ini paling baik dievaluasi pada iris yang tidak diberi midriatikum karena munculnya pembuluh darah selalu mulai dari perifer iris atau pada iridektomi perifer. ${ }^{5}$ Sudut bilik mata depan dievaluasi dengan gonioskopi tanpa dilatasi pupil. Pada CRVO yang ringan mungkin ditemukan sudut kamera depan terbuka dengan sedikit neovaskularisasi. Pada CRVO yang berat dapat ditemukan sudut tertutup dengan sinekia anterior totalis. ${ }^{9}$

Pemeriksaan funduskopi indirek dilakukan untuk mengevaluasi seluruh kuadran retina dan mendapatkan informasi yang lengkap tentang kondisi makula, diskus optikus dan pembuluh 
darah retina. Perdarahan retina terdapat di semua quadran retina. Bentuk perdarahan bervariasi, mulai dari perdarahan superfisial, dot and blot, atau perdarahan pada lapisan retina yang lebih dalam. Perdarahan dapat ringan atau berat, juga akan berbeda gambarannya pada perdarahan dengan onset baru dengan perdarahan yang onsetnya sudah lama. Jika baru terjadi perdarahan yang berat seluruh fundus dapat tertutup bayangan merah (darah), gambaran yang demikian disebut "blood and thunder appearance".10,11 Gambaran lain yang sering ditemukan pada funduskopi indirek, yaitu $^{10,11}$ :

- Cotton wool spot, lebih sering ditemukan pada iskemik CRVO. Cotton wool spot dapat diserap dalam waktu 2-4 bulan

- Neovaskularisasi pada diskus optikus (NVD, Neovascularization of the disk). NVD dapat menyebabkan perdarahan vitreous

- Neovaskularisasi di tempat lain (NVE, Neovascularization elsewhere). NVE lebih jarang ditemukan daripada NVD, adanya NVE mengindikasikan iskemia retina yang beratOptocilliary shut vessels yaitu pembuluh darah abnormal pada diskus optikus yang mengalirkan darah dari sirkulasi retina ke sirkulasi koroid sebagai mekanisme kompensasi

- Perdarahan pre retina atau vitreous

- Edema makula, dapat pula disertai eksudat

- Edema makula sistoid

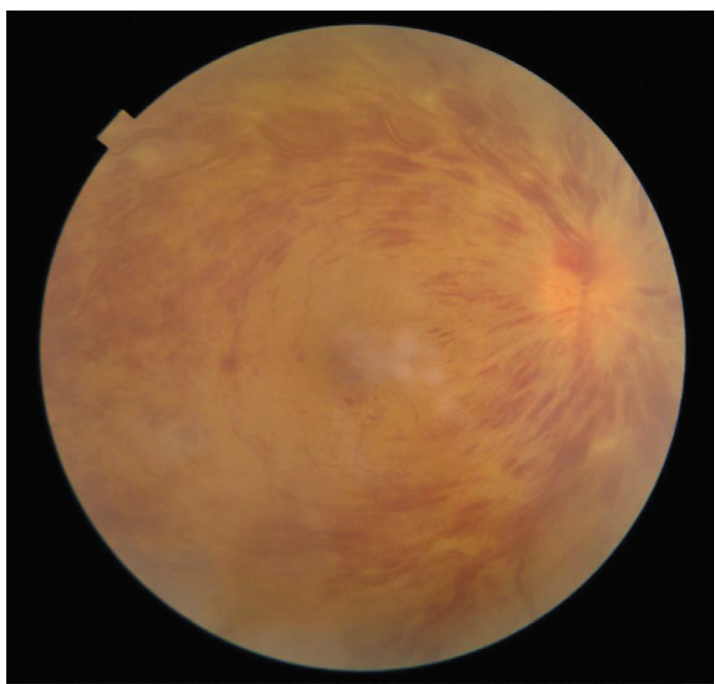

Gambar 1 CRVO pada wanita muda, onset baru dengan keluhan penglihatan kabur tiba-tiba. Terdapat perdarahan flameshaped di seluruh quadran retina, edema papil nervus optikus dan edema makula
- Macular hole

- Atrofi papil

- Perubahan pigmen pada makula

\section{Pemeriksaan Pencitraan Penunjang}

Pemeriksaan pencitraan peunjang dibutuhkan untuk mengetahui tingkat keparahan penyakit dan prognosis sebagai bahan pertimbangan tindakan atau tatalaksana yang akan dilakukan. Pemeriksaan pencitraan penunjang yang sering dilakukan yaitu Color Doppler dan Optical Cohorence Tomography (OCT). ${ }^{12}$ Color Doppler sering dipilih di karena non-infasif dan dapat menilai sirkulasi retrobulbar secara kuantitatif. OCT adalah teknologi pencitraan noninvasif, non-kontak, transpupil yang mampu menggambarkan struktur retina in vivo dengan resolusi aksial 1-15 $\mu \mathrm{m}$. OCT menunjukkan kondisi fotoreseptor dan lapisan sel ganglion. OCT terutama digunakan untuk mengamati edema makula secara berkala dan responnya terhadap pengobatan. ${ }^{3,12}$ Pemeriksaan fundus dengan Fluorescein Angiography (FFA) dapat mendokumentasikasn derajat obstruksi, tingkat keparahan gangguan permeabilitas kapiler serta dapat menunjukkan seberapa luas daerah non-perfusi pada retina setelah perdarahan. Pemeriksaan FFA memberikan gambaran yang lebih baik jika menggunakan kamera fundus yang bersudut luas karena dapat mencakup perifer fundus dan posterior pole dimana paling sering terjadi non-perfusi kapiler setelah resolusi perdarahan intraretina. ${ }^{13}$

FFA pada impending CRVO akan menunjukkan sedikit peningkatan pada waktu sirkulasi retina. FFA pada non-ischemic CRVO akan menunjukkan perlambatan yang sangat jelas pada arteriovenous transit time yaitu lebih dari 20 detik. FFA pada ischemic CRVO akan menunjukkan daerah-daerah yang tidak mendapat perfusi kapiler (non-perfusi). Risiko neovaskularisasi meningkat pada area non-perfusi yang lebih luas daripada 10 area diskus optikus. $^{13}$

\section{Manajemen Faktor Risiko}

Terdapat dua tujuan utama dalam penatalaksanaan CRVO yaitu (1) mengidentifikasi dan mengontrol faktor risiko mayor yang mencetuskan CRVO dan (2) diagnosis dan tatalaksana komplikasi yang mengancam penglihatan, terutama edema makula dan neovaskularisasi. ${ }^{6}$ Manajemen faktor risiko yang baik dapat mengurangi keparahan penyakit, mengurangi risiko komplikasi serta melindungi mata yang belum terdampak.

Apabila secara klinis ditemukan tanda CRVO tanpa gejala perburukan visus, maka manajemen faktor risiko sistemik dapat segera 


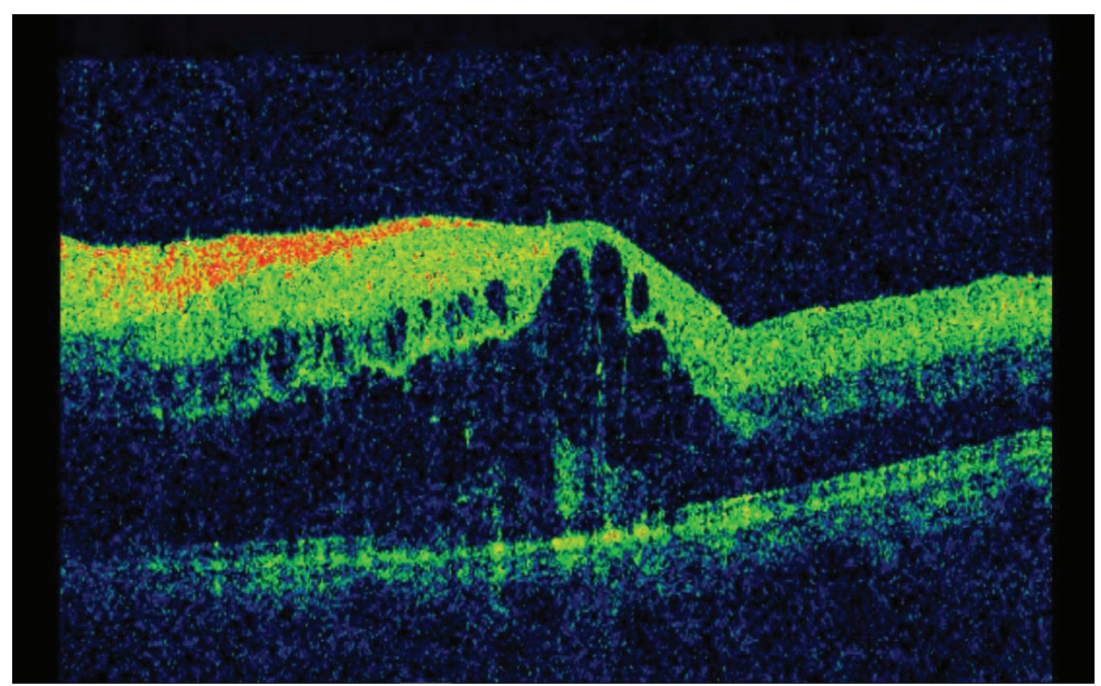

Gambar 2 Gambar OCT dari pasien yang sama pada hari yang sama menunjukkan edema makula

dilakukan. Tekanan darah tinggi serta glaukoma harus selalu dieksklusi atau segera diterapi apabila ada. Manajemen faktor risiko yang baik dapat memperlambat bahkan menghentikan progresifitas CRVO. ${ }^{6}$

\section{Modalitas Penatalaksanaan Komplikasi Crvo}

Terdapat berbagai modalitas terapi dalam penatalaksanaan komplikasi CRVO, yaitu:

1. Anti-vascular endothelial growth factors (anti-VEGF)

Anti-VEGF telah menjadi modalitas standar dalam penatalaksanaan CRVO. Terdapat tiga agen anti-VEGF yang saat ini dipakai untuk mengobati edema makula terkait CRVO yaitu Ranibizumab, Bevacizumab dan Aflibercept. Ranibizumab dan Aflibercept saat ini telah terdaftar di FDA (Food and Drug Administration) dan telah mendapatkan authorisasi marketing dari EMA (European Medicines Agency) sebagai terapi edema makula yang berkaitan dengan CRVO. Bevacizumab sendiri belum mendapat ijin legal sebagai injeksi intraokular (off-label, unlicenced use). ${ }^{14}$

Injeksi anti-VEGF memerlukan dosis ulangan. Ketiga agen anti-VEGF saat ini sedang banyak menjadi objek penelitian untuk menentukan berapa rentang waktu pemberian dosis ulangan yang efektif sehingga dapat meminimalkan beban, biaya dan risiko injeksi. ${ }^{15}$

2. Kortikosteroid intraokular

Kortikosteroid intraokular terbukti efektif dalam mengatasi edema makula terkait CRVO karena memiliki sifat anti-inflamasi, menghambat sitokin yang terlibat dalam perjalanan penyakit tersebut, termasuk VEGF, interleukin-6, intercellular adhesion molecule-1 dan monocyte chemoattractant protein- $1 .{ }^{15,16}$ Kortikosteroid intraokular dipakai sebagai terapi lini kedua pada kasus-kasus yang tidak merespon terhadap pemberian anti-VEGF, namun di beberapa pusat pelayanan kortikosteroid intraokular mungkin dipakai sebagai lini pertama karena lebih mudah didapat dan harganya lebih murah. ${ }^{17}$

Triamcinolone acetonide tersedia dalam dua dosis injeksi intravitreal yaitu injeksi $4 \mathrm{mg}$ dan $1 \mathrm{mg}$. Clinical Trial SCORE-CRVO membandingkan profil efektifitas dan keamaan kedua dosis injeksi intravitreal tersebut dan didapatkan bahwa kedua dosis tersebut efektif meningkatkan ketajaman penglihatan pada edema makula terkait CRVO, namun meningkatkan angka operasi katarak pada 12-24 bulan setelah onset terapi serta meningkatkan penggunaan obat-obatan penurun tekanan bola mata dalam waktu 12 bulan setelah terapi. Dosis $1 \mathrm{mg}$ menunjukkan keunggulan pada profil keamanan dibandingkan dengan dosis $4 \mathrm{mg} .{ }^{18}$ Saat ini agen kortikosteroid intraokular yang tersedia secara luas adalah triamcinolone acetonide, namun agen baru dalam bentuk implant kortikosteroid menunjukkan keunggulan dibandingkan dengan injeksi karena memungkinkan pelepasan zat aktif secara perlahan, meningkatkan durasi kerja dan mengurangi toksisitas.

Belum ada penetelitian skala besar yang membandingkan efektivitas kortikosteroid intraocular dengan anti-VEGF. Beberapa penelitian berskala kecil seperti yang dilakukan oleh Gado AS, dkk yang membandingkan efektifitas Bevacizumab dengan implan dexamethasone (Ozurdex) pada 60 pasien dengan non-ischemic CRVO, tidak ditemukan perbedaan yang signifikan dalam BCVA letter score maupun ketebalan makula pada kedua kelompok dalam waktu 6 bulan. Penelitian tersebut juga menemukan bahwa terjadi peningkatan tekanan intraokular yang signifikan pada grup dexamethasone dibandingkan dengan grup bevacizumab. ${ }^{19}$ Penelitian serupa oleh Ding, dkk menunjukkan hasil yang serupa dalam waktu 9 bulan. ${ }^{20}$

3. Laser

Penggunaan laser dalam terapi RVO telah lama menjadi kontroversi jauh sebelum ditemukannya anti-VEGF. Central Vein Occlusion Study Group (CVOS) pada tahun 90-an telah mengkonfirmasi bahwa grid-pattern photocoagulation faktanya memang mengurangi edema makula, namun tidak memberikan perbaikan 
visus pada pasien edema makula terkait CRVO. $^{21}$

4. Dense peripheral paretinal photocoagulation (PRP).

Dense peripheral paretinal photocoagulation (PRP) masih digunakan untuk mengatasi komplikasi neovaskularisasi iris dan retina pada CRVO. PRP tidak meningkatkan visus, namun dapat mengurangi resiko neovaskularisasi iris dan glaucoma neovaskular. Setelah era anti-VEGF maka penggunaan PRP sudah banyak berkurang. ${ }^{22}$

\section{KESIMPULAN}

CRVO merupakan penyakit vascular mata yang sering dijumpai pada praktek sehari-hari dan bertanggung jawab atas sejumlah kebutaan dan morbiditas pada mata. Diagnosis dini dan penatalaksanaan yang tepat terkait faktor risiko sistemik maupun kondisi mata sangat penting untuk meningkatkan hasil dan prognosis ketajaman penglihatan.

Penatalaksanaan CRVO saat ini sudah mengalami perkembangan yang pesat dengan banyaknya modalitas baru termasuk anti-VEGF dan implant kortikosteroid yang telah terbukti secara klinis mampu mengobati edema makula terkait CRVO. Baik injeksi anti-VEGF maupun kortikosteroid intravitreal memerlukan injeksi berulang, namun sampai saat ini belum ditemukan rentang waktu optimal dimana terapi ulang harus dilakukan. Penelitian lebih lanjut masih diperlukan terutama untuk menentukan rentang waktu terapi sehingga meminimalkan beban, biaya serta risiko injeksi.

\section{DAFTAR PUSTAKA}

1. Jenkins T, Su D, Klufas M. RVO Overview: Epidemiology, risk factors, and clinical features of this common cause of retinal vascular disease. Retina Today. 2018, Apr 40-3.

2. Rogers s, McIntosh RL, Cheung $\mathrm{N}$, et al. International Eye Disease Consortium. The prevalence of retinal vein occlusion: pooled data from population studies from United States, Europe, Asia, and Australia. Ophthalmology.2010;117(2):313-319.e1.

3. Kooragayala LM. Central Retinal Vein Occlusion (CRVO). Medscape 2019. Available online at: https:/emedicine. medscape.com/article/1223746-overview\#a4

4. Stem MS, Talwar N, Comer GM, Stein JD. A Longitudinal analysis of risk factors and outcome in patients with retinal vein occlusion. J Thromb Thrombolysis. 2010;30(1):16-22.

5. Buehl W, Sacu S, Schmidt-Erfurt U. Retinal Vein Occlusion. Dev Ophthalmol 2010; 46:54-72.

6. Keren S, Loewenstein A, Coscas G. Pathogenesis, prevention, diagnosis and management of retinal vein occlusion. World J Ophthalmol. 2014;Nov 12;4(4) 92-112.
7. Central vein occlusion study group. Natural history and clinical management of central retinal vein occlusion. Arch Ophthalmol 1997;115:489-91.

8. Hayreh SS, Zimmerman MB. Fundus changes in central retinal vein occlusion. Retina 2015;35(1):29-42.

9. Hayreh SS, Podhajsky Pa, Zimmerman MB. Natural history of visual outcome in central retinal vein occlusion. Ophthalmology 2011;111: 1087-95.

10. Shroff D, Kothari A, Bhatia G, Gupta C. Clinical Diagnosis of Retinal Vein Occlusion. International Journal of Ophthalmic Research 2016; 2 (2): 137-142. Available online at: www.ghrnet.org/index.php/IJOR/article/ view/1548/2043

11. American Academy of Ophtalmology Preferred Practice Pattern Comittee. Preferred Practice Pattern ${ }^{\circ}$ Guidelines. Retinal Vein Occlusions. San Francisco, CA: American Academy of Ophthalmology; 2016. Available at: www.aao. org/ppp

12. Schütze C, Schmidt-Erfurt U. Imaging for BRVO and CRVO.: OCT images layers of the retina that are relevant to the evaluation of RVO. Retina today. 2011, May 63-8.

13. Pichi F. Central Retinal Vein Occlusion. AAO Eyewiki. 2019 available online at: www.eyewiki.aao.org/w/index. php?title=Central_Retinal_Vein_Occlusion

14. Ashraf M, Souka AAR, Singh RP. Central Retinal Vein Occlusion: Modifying Current Treatment Protocols. Eye; 2016: 30: 505-514.

15. Thorell MR, Goldhardt R. Update in the Management of Macular Edema Following Retinal Vein Occlusions. Curr Ophthalmol Rep. 2016 March; 4(1): 38-47.

16. Maggio E, Polito A, Guerriero M, Pertile G. Intravitreal Dexamethasone Implant for Macular Edema Secondary to Retinal Vein Occlusion: 12 month follow-up and prognostic factors. Opththalmologica.2014;232;207-15.

17. Gallemore RP, Wallsh J, Behnam S, Gallemore E. What The Clinical Trials Tell Us- Demystifying the studies for some practical clinical guidelines. Retin today. 2013 Apr:64-7.

18. Ip MS, Scott IU, VanVeldhuisen PC, et al. A Randomized trial comparing the efficacy and savety of intravitreal triamcinolone with observation to treat vision loss associated with macular edema secondary to central retinal vein occlusion: the Standart care vs Corticosteroid for Retinal Vein Occlusion. Arch Ophthalmol. 2009;127:1101-14.

19. Gado AS, Macky TA. Dexamethasone intravitreous implant versus bevacizumab for central retinal vein occlusion-related macular oedema: a prospective randomized comparison. Clinical and Experimental Ophthalmology. 2014. Available at https://doi.org/10.1111/ceo.12311

20. Ding X et al. Prospective study of intraviteral triamcinolone acetonid versus bevacizumab for macular edema secondary to central retinal vein occlusion. Retina; 2011:31(5):838-845

21. Evaluation of grid pattern photocoagulation for macular edema in central vein occlusion. The Cental Vein Occlusion Study Group M report. Ophthalmology. 1995; 102;1425-33.

22. Esmaili DD, Boyer DS. Recent advances in understanding and managing retinal vein occlusions. F1000Res. 2018;7:467.

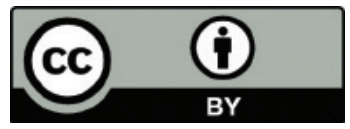

This work is licensed under a Creative Commons Attribution 